Volume 2 No. 2, Desember 2017

P ISSN 2442-594X | E ISSN 2579-5708

http://journal.iainlangsa.ac.id/index.php/tibyan

\title{
WOMEN INTERPRETATIONS ON QUR'AN, ISLAMIC INSTITUTIONS AND COMMUNITIES
}

\author{
Interpretasi Alquran Terhadap Wanita, Lembaga Keislaman dan Lembaga Sosial
}

\author{
Suparwany \\ Institut Agama Islam Neeri Langsa, Aceh \\ wani_nga@yahoo.com
}

\begin{abstract}
Absrak
Makalah ini mengkaji ide-ide yang diajukan oleh beberapa feminis Muslim untuk mengabaikan Islam dari perspektif perempuan yang memberi cahaya khususnya pada Alquran, institusi Islam dan praktik sosial ajaran Islam di masyarakat Muslim. Peninjauan ini akan memokuskan pada lima penulis feminis termasuk Aminah Wadud, Saba Mahmood, Haideh Moghissi, Barlas, dan Margot Badran. Pikiran mereka akan penulis ulas satu demi satu beserta dengan komentar dan konribusi pemikiran mereka terhadap kaum feminis.
\end{abstract}

Keywords: Alquran, Lembaga Keislaman, Sosial

\begin{abstract}
This paper examines ideas raised by several Muslim feminist to overlook Islam from women perspectives that shed a light especially on the Qur'an, Islamic institutions and social practices of Islamic teaching in Muslim society. The review contested five feminist writers including Aminah Wadud, Saba Mahmood, Haideh Moghissi, Barlas, and Margot Badran. The thoughs represent one after another that followed by comments on the contributions.
\end{abstract}

Keywords: Qur'an, Islamic institutions, Communities

\section{Preliminary}

This paper examines ideas raised by several Muslim feminist to overlook Islam from women perspectives that shed a light especially on the Qur'an, Islamic institutions and social practices of Islamic teaching in Muslim society. The review contested five feminist writers including Aminah Wadud, Saba Mahmood, Haideh 
Moghissi, Barlas, and Margot Badran. The thoughs represent one after another that followed by comments on the contributions.

\section{Aminah Wadud: Qur'an and Woman Rereading the Sacred Text from a Woman's Perspective}

Aminah Wadudin her writing on Qur'an and Woman Rereading the Sacred Text from a Woman's Perspective explores how the perception of the laters scholars and societies influences the interpretation of the Quranic verses on women. In her view there is no single method of Quranic exegesis that is fully objective. She interprets the Quran in two ways; through 'reading' (direct interpretation while reading the Qur'an), and through exegesis (individual perspectives to approach the Qur'an more objectively). She divides the interpretation of women in the Quran into three categories: traditional tafsir (exegesis) (exclusively written by males, which included males' experiences and ignored females' experiences), reactive tafsir (mostly rejections from the feminist sides), and lastly comprehensive and holistic reading through welt anschauung. ${ }^{1}$

She also uses the hermeneutic approach ${ }^{2}$ which covers; the context, the grammar and the whole text of the Qur'an. Her main idea is that both men and women are essential in the creation of humanity and equality. ${ }^{3}$ She also emphasizes the idea of taqwa (piety) (p. 36); the closest person to God is the most pious person, regardless of gender. In addition, she looks at various roles of women given in the Qur'an in order to see the 'proper' role and positions of women in the Muslim worlds. She examines egalitarian system in the Quran in discussing the hereafter and its overall reward in heaven including heavenly angels . Lastly she provides philosophical analysis on gender in the Qur'an, and overcomes some traditional interpretations which in her opinion disadvantaged women.

\section{Tafsir bil Ma'tsur:}

What is obvious to me is the fact that, although she rejects traditional interpretations of the Qur'an, in fact, whether she acknowledges or not, she uses it in her study; namely tafsir bil ma'tsur (interpretation of Quranic verses using other Qur'anic verses and using hadith). However, she ignores to employ hadith as part of the method for her use of tafsir bil ma'tsur.

One may think it is fine to just interpret one text with the text itself. however, it is a flaw in the field of tafsir (exegesis). Because hadith clearly play several roles toward the Qur'an, including as bayan ijmali (explains the general meaning of the Qur'an), bayan ta'kid (emphasizes the importance of what the Qur'an has said) and bayan tafsili (explains a law or something which is mentioned unclearly in the Qur'an). For example the Qur'an

\footnotetext{
${ }^{1}$ Amina Wadud, Quran and Women : Rereading The Sacred Tect From A Woman' Perspective, (New York : Oxford University Press, 1999), p. 1-2, 5

${ }^{2}$ Wadud, Quran and Women..., p. 3

${ }^{3}$ Wadud, Quran and Women... p. 12
} 
instructed Muslims to perform prayers (Aqim al-shalah), however the Qur'an does not explain how to do the prayers. The hadith explains the process of prayers in detail (pray as you see the way I pray- Alhadith). Based on the hadith, all Muslims in the world perform shalat by imitating the way the Prophet performed it.

Therefore, the role of hadith is important in the interpretation of the Qur'an as a complementary explanation, to clarify what is unclear (mutasyabihat) in the Qur'an, and to emphasize what is mentioned as something important in the Qur'an (ta'kid). Hadith must be used together in this method in order to achieve a comprehensive understanding of the interpretation of the Qur'an. If, an interpreter cannot find any relevance information in hadith about the verses $\mathrm{s} / \mathrm{he}$ is interpreting, then $\mathrm{s} / \mathrm{he}$ can usehis/her rationality.

\section{Asbabun Nuzul:}

Using the hermeneutic approach in understanding the Qur'an gives us a new perspective in understanding the Qur'an. However, Wadud also needs to use the most important variable in accordance with Qur'anic interpretations namely asbabun nuzul (the specific case, specific historical background or the underlying context when the Prophet received the verses). Although she uses the Arabic historical context in $\mathbf{5 7 0}$ $\mathrm{AD}$ to understand the societal breakdown of Arabic culture at that time, this cannot replace the function of asbabun nuzul. Almost all the verses had their own individual or specific cases or historical background before the Prophet received them. For example the Qur' an said 'Do not pray while you are drunk'.It means you can have had beers as long as you were not drunk when you prayed. The historical background of this verse because, at that time people were newly become Muslim. They could not leave their habit of consuming alcohol yet. But after sometimes, they became disciplined not to be drunk before prayer times, and they slowly could leave the beers, then the Qur'an Said: “ Beer is bad, leave it at all times".

Therefore, in interpreting the Qur'an, although an interpreter uses a modern approach and has a good command of Arabic, these competences cannot simply diminish the importance of the Qur'anic variables such as asbabun nuzul, if s/he wants to gain a holistic understanding about the verses. Asbabun nuzul is not a method, it is part of the factors or reasons why the Quran descend to the earth.

\section{Key term: Hurun 'Ain}

Her explanation about key terms such as 'khalaqa' (initiation of creation, or a creative process), ${ }^{4}$, 'sawwara' (to 'form', shape, design, perfect), 'min' nafs, zawj, and khalifah ${ }^{5}$ in the Qur'an is wide and comprehensive, and in accordance with Arabic grammar and syntax systems. Unfortunately, she does not explain grammatically the gender of hurun 'ain (heavenly angels) mentioned in the Qur'an. Are they males or females? Or do they have gender attributes or do they not? The gender stat us of hurun ain

\footnotetext{
${ }^{4}$ Wadud, Quran and Women... p. 16-17

${ }^{5}$ Wadud, Quran and Women... p. 23
} 
based on a grammatical explanation is important because they are angels in heaven provided for pious people (men and women) as reward.

Even if she cannot find any gender status grammatically for the term hurun 'ain, in Arabic, she has to mention it clearly in her book. In fact, she jumped into describing the social meaning of hurun 'ain (she explains 'hury' in the Arabic social context as beautiful women with wide black eyes and white skin). Social explanation is good, but grammatical explanation is important to avoid misunderstanding in interpreting every single issue found in the Qur'an, in relation to gender discussion.

In conclusion, Wadud has contributed a great deal in explaining gender issues, and encountering male domination in interpreting verses about women. God, in fact rewards people not based on their gender status but based on their deeds and pities (taqwa). And regardless some weaknesses, she has done her best to promote the rights of women in the Islamic world.

\section{Barlas: Believing Woman in Islam}

Barlas in her book Believing Women in Islam explains three main points; patriarchal domination in interpreting religious texts (including in Islamic and other religious books), sexual and gender issues, marriages and families. By doing so she urges people to interpret the Qur'an liberally ${ }^{6}$, and to free the interpretations from patriarchal prejudices. She also explains widely about liberation and egalitarian system in the Qur'an, Likewise, she also encourages women to play role in interpreting Islamic resources in order to get balance ideas on gender issues; since so far men dominate this field and women's voices are not significant. ${ }^{7}$

In explaining the patriarchy, she relates her discussion to tauhid (the oneness of God $)^{8}$, the very core idea in Islam. This tauhid explanation is beneficial to reject the masculinity of god which is usually justified in some religions (Barlas criticizes god as father and son). In the first stage, there is nothing new about her idea on tauhid in relation to egalitarian and gender issue in Islam. Muslim teachers (ustadz) in Indonesia have repeatedly mentioned tauhid in mosques or in Islamic teaching occasions (pengajianpengajian); that God is neither a man nor a woman. Moreover, the implementation of Islam in Indonesia in term of women issues, was not as bad as or as serious as women in other countries such as Pakistan, and the Middle East, where in some cases women receive very poor treatment, due to misconception on Islamic teaching. And although there are radical Muslim groups in Indonesia which Qur'anic interpretation dominated by 'male interpretations', most of the Indonesian Muslim do not follow their ideas. However, having a background as a Pakistan woman and experienced life in Pakistan, it is

\footnotetext{
${ }^{6}$ Asma Barlas, believing Women in Islam:Unreading Patrarchal Interpretations of the Qur'an, (Austin : University of Texas, 2002), p. 10

${ }^{7}$ Asma Barlas, believing Women in Islam..., p. 9

${ }^{8}$ Asma Barlas, believing Women in Islam..., p.12-13, 94-95
} 
understandable why Barlas views on this 'male interpretations' become a serious issue in 'a Pakistan context'.

The second issue raises in her book is sexuality and gender in Islam in relation to sameness, difference, and equality between male and female. The Quran in her opinion, acknowledged the concept of sameness; the God had created male and female from 'one self' (nafs wahid also means 'one soul'), and biological dissimilarity do not make man and woman difference from moral perspectives. So far the interpreters' favorite verse was 'woman (eve) was created from man (Adam)'. There was an ignorance toward the verse on 'nafs wahid'. However, it does not mean that this is a new idea she proposes in explaining the 'sameness'. In fact, in the perspective of Arabic syntax the word 'huwa' does not merely and always mean 'he', but it also shares with and inclusively means 'she'. So, it is not Barlas who proposed this idea, in fact it was widely accepted and understood in Arabic syntax.

The third issue raises in her book is about marriage and family life. In her view, although there are assumptions about patriarchy domination in marriages, Islam does not recognize this system. In her opinion, this assumptions emerge because male interpreters do not connect the texts with the contexts when the Prophet received the verses on the marriage. Her explanation is totally true, although texts and contexts approaches she uses, again, is not new. In the field of tafsir (Islamic exegesis) 'asbabun nuzul' (text and context) is a 'must' component in interpreting the Qur'an.

Barlas was excellent in using huge number of references, however, those references hinder her own genuine idea on gender and Islam to appear. It seems as if the ideas she has shown were repetitions from what have been said by previous scholars in the field of gender and Islam, such as the ideas on nafs.

In addition, although Barlas uses many resources, she ignores most well known Arabic classical tafsir such as Tafsir Jalalain, Tafsir Ibnu Kasir, Tafsir al-Thabari, Tafsir Thaba' Thaba'i (all are written in Arabic). If she does use the tafsir books in her reference or she criticizes them by underlining point by point of the issue, I think her work will become more unique, compares to when she only refers to the most recent studies on Gender and Islam. She also does not use or criticise the methods known in tafsir such as tafsir bil ma'tsur (interpretation on Qur'anic verses by using hadits), tafsir maudlu'i (interpretation based on topics), and so on in comparison to hermeneutic appoach. It is useful to see the weaknesses of each appoaches.

In conclusion, Barlas proposes the ideas about egalitarian in Islam and liberation in interpreting Islamic sources from patriarchate domination. However she does not genuinely explore her own ideas since some of the ideas she proposes are already widespread in Islam. In addition, she does not use and criticize the primary classical tafsir, and she mostly refers her ideas to the previous scholar's findings. However, in the positive side, Barla's work is valuable, since she was able to put 'these ideas which are already available in Islamic studies' into a book. So that it become a real contribution for academic work. 


\section{Saba Mahmud: Saba Mahmood, Politics of Piety: The Islamic Revival and the Feminist Subject}

Saba Mahmood conducted field work on women's mosque movements in three different mosques in Cairo from 1995-1997. The three mosques, Umar, Nafesha, and Ayesha represent a variety of socioeconomic conditions of the participants; from upper, middle, to lower class. Umar Mosque is a model of high class, Nafesa Mosque reflects a middle class cluster, whereas Ayesha Mosque situated in the most impoverished surroundings on the outskirts of Cairo, is associated with the largest Islamic non profit organization in Egypt, Al-Jam'iyya al-Shar'iyya, which offers broad well-being services to the people in surrounding neighborhoods. ${ }^{9}$

The movement emerged as part of religious awareness in the 1970s and has changed the role of mosques in Egypt, from male Muslim dominatedinstitutions throughout history, either as fuqaha' (public Islamic implementers), imam (worship leaders), du'a' (preachers), mufassir (interpreters), or mufti (authority for any religious regulations), to female religious activities and their Islamic scholastic practices linked with public cavity, which purpose is to achieve piety. The activities of this gender group demanded the government's awakening to sociocultural ethos and gender issues in Egypt. ${ }^{10}$

In general, Mahmood mainly explores the mosque group conversations including the preachers, and the attendants comprised of a variety of ages and social statuses. The main topic of discussion is virtuous practices to engage with modern problems at pragmatic levels. For example, how to behave modestly either on public transport, or in schools or offices where there are no pious procedures of sex separation (p. 55). Furthermore, discussions on the transformation of religion into convention, for instance wearing the veil (hijab) as a custom rather than as a religious duty,necessitates responsibility to behave in a truly modest way in daily life, has become the concern of the movement. ${ }^{11}$

Mahmood also reckons the movement as a response to growing disappointment with Egypt's increasing secularization. Mahmood examines what the participants mean by secularization, what facet of social conduct they considered most notable in this process, and what form of religiosity they sought to renew through their activities. She connected those questions with the context of current Islamic revivals, and the relationship of these current trends to the history of Egyptian religious activities in the last century. ${ }^{12}$

\footnotetext{
${ }^{9}$ Saba Mahmood, Politics of Piety: The Islamic Revival and the Feminist Subject, (Cairo: Princeton Uniersity Press, 2004), p. 2

${ }^{10}$ Mahmood, Politics of Piety..., p. 2-4

${ }^{11}$ Mahmood, Politics of Piety..., p. 50-51, 56

12 Mahmood, Politics of Piety..., p. 43
} 
A clear example according to Mahmood's participants is the perception toward the accomplishment of 'ibadat (worships) that have been gradually transformed to the stat us of customs or conventions, such as hanging lanterns from doorways or baking cookies during ramadlan, or eating meat on al-'id al-kabir. The movement's concern is how to adjust their religion while at the same time moving with the world (p. 44, 48-49). The mosque movement's solution to Egypt's secularization problems does not directly confront the political order. For example, in the last three decades supporters of the Islamist movement have set up a number of Islamic schools, in order to resist the secular model of modern Egyptian education. ${ }^{13}$

Mahmood also provides a comprehensive explanation by supplying a historical account of the movement and its linkage within the state, and examines the data on the women's organization and their activities, Mahmood reaches a conclusion that the piety movement is purely a moral and self oriented project.

The writer also analyzes the concepts of self, moral agency, and politics, as the underlying culture for the movement. ${ }^{14}$ In Mahmood's view, the women in the movement are seen as an active social agents. Mahmood explores the notion of human agency and political and moral autonomy in relation to the study of humans in Islam. She suggests alternative ways of thinking about agency. In her opinion, agency in the case of Egypt is not necessarily based on freedom and rights or types of gender fashion reciprocal to patriarchal contexture, or based on the concept of western feminism, but it takes place in religious definitions and conducts.

Mahmood comes to a conclusion that the movement tends to focus on moral renewal, escape from secularization and avoids direct involvement in the political arena. Moreover, in 1996 the Egyptian government started to control the activities of da'wa and preachings more strictly, by requiring both male and female preachers to undergo a two year training program in da'wa administered by the Ministry of Religious Affairs in order to get a state license to preach. Surveillance of women's mosque lessons, or a government employee with a tape recorder sitting at the back of the mosque recording, is now a common sight.${ }^{15}$ By avoiding active and pragmatic political activities the movement have chosen the safest way to run their program.

What happened in Egypt in terms of the spirit of Islamic revivalism has some similarities with Indonesia. Many Indonesian women, together with men, join Islamic preachings where the preachers consists of males and females. The impact of secularization in Indonesia was also answered by building modern Islamic schools suchas Al-Azhar schools, and modern pesantren (Islamic boarding schools), in addition to the existing traditional pesantren. More radically, various institutions ranging from liberal to the most fundamental emerged in Indonesia. After the fall of the new order regime, the Indonesian government established freedom of press. As a result, society, including

${ }^{13}$ Mahmood, Politics of Piety..., p. 48

${ }^{14}$ Mahmood, Politics of Piety..., p. 5

${ }^{15}$ Mahmood, Politics of Piety..., p. 75-76 
Islamic groups, have more freedom to speak, voice their opinions, and even set up political organizations. This gives Indonesian Muslim women and men more opportunity and freedom to express their Islamic and political views, which is difficult to do in Egypt. However, although Indonesians mosques have Islamic teachings, they only focus on prayers matters, not entering further into the field of gender or other serious social political issues.

\section{Haideh Moghissi Feminisme dan Fundamentalisme Islam}

Haideh Moghissi's book investigates the relationship between feminist and fundamentalist Islam. Moghissi begins with an attack onMuslim fundamentalist groups by exploringpolitical abuse towards the women in these regimes such as abductions, systemic rapes, murders, slavery and famines in countries such as Afghanistan, Algeria, Sudan, Iran, and Pakistan. ${ }^{16}$ Regardless of the fact that Moghissi uses the term Islamic feminism, she is indefinite about the existence of this expression in the Islamic world and believes this phrase is possibly only a political idiom. ${ }^{17}$

The chapters discuss fundamentalist groups and their origins, feminist Islam and modernity, sexuality in old Islamic interpretations, orientalist and post modernist attitudes regarding fundamentalists and Islamic feminists, Islamisation policies influencing women by fundamentalist states and lastly the feminist and their discontent.

In the first chapter, Moghissi explores the Islamic outlook on women's sexuality. She proposes that religion has an authoritative role that influences the position of women in society, and Islamic political discourses promote restraint and control of female sexuality. ${ }^{18}$ Moghissi claims that female sexuality in Islam and the ethical behavior of women has been integrated into many areas of life such as policies, customs, institutions as boundaries for womens lives, options, and community involvement and that fundamentalist attitudes towards women's sexuality have degraded women's conditions. In comparison, Moghissi states women in Western societies do not get satisfactory treatment and they are still to achieve true equality with men.She also views other religions besides Islam as having similar attitudes. ${ }^{19}$

Moghissi analyzes the relationship between orientalism and Islamic feminism in the second chapter. She highlights that although there is no direct relationship between feminism and orientalistism, the orientalists have provided room for growth by defining the notion of 'otherness', which is used to circumscribe Islamic fundamentalism and its feminist interpretations. Moghissi refers to Edward Said and agrees that orientalists emphasise the differences between the West and the East which intends to accentuate Western superiority over the East. ${ }^{20}$ Moghissi also criticizes

\footnotetext{
${ }^{16}$ Haideh Moghissi, Feminisme dan Fundamentalisme Islam, (Yogyakarta: Lkis, 2005), p. 2

${ }^{17}$ Moghissi, Feminisme dan Fundamentalisme Islam..., p. 182, 198

${ }^{18}$ Moghissi, Feminisme dan Fundamentalisme Islam..., p. 19, 23

${ }^{19}$ Moghissi, Feminisme dan Fundamentalisme Islam..., p. 185

${ }^{20}$ Moghissi, Feminisme dan Fundamentalisme Islam..., p. 45-46, 48
} 
orientalist attitudes thatstressthe poor condition of Middle Eastern women, as they use thisas a tool to attack Islam.

Besides attacking the fundamentalist movements and the orientalists in early chapters, chapter three provides a wide range of criticism aimed at Western post modernist intellectuals who tend to give concessions to radical groups, regardless of their poor treatment of women. ${ }^{21}$ In positive terms, post modernism is concerned mostly with problems of sexuality, gender, ethnicity and it makes those problems its political agenda.Moghissi focuses her research on post modernism andits affects on Middle Eastern politics ${ }^{22}$, especially in relation to cultural discourses. Moghissi analyzes post modernists, their framework of thinking such as their failure to conquerimperialism, colonialism, and racism, their focus on ethnocentrism, and their rejection of Marxist ideas, being the ideological framework thathas influenced Moghissi significantly. ${ }^{23}$

In chapter four Moghissi defines the origins, characteristics, similarities and differences amongst Islamic fundamentalists. She refers to Islamic fundamentalists in neutral terms as 'Islamists'. ${ }^{24}$ In her view, the groupsshare the same characteristics to a large degree.For example, they are against democracy but use the product of democracy $^{25}$, they have the same aim to reconstruct Muslim society, gender roles areallocated to men and women according to their nature and biological appearances, and they wish to re-live the interpretation of women according to Islamic doctrine literally. ${ }^{26}$ On the other hand, Moghissi states there are similarities between fundamentalist groups and post modernism. Both reject the West and appreciate everything importedfrom outside the West and they criticize capitalism and reject the excessive consumerist behaviors of the West. ${ }^{27}$ These similarities tells us why post modernist groups embrace fundamentalism, despite their bad treatment ofwomen.

In addition, chapter five discusses women, modernity and social change and the benefitsand disadvantagesthis brings women. Moghissi believes the majority of women in the Middle East and South Africa did not benefit from modernism or modernity, even though they have had contact with modernization. In her view, modernism and modernity werequasi-projects, because they failed to make people theperfect human beingsthat it promised. Likewise, she views capitalism and industrialism as not delivering advantages for women. Although these developments helped to free some women from male dependency, it strengthened patriarchal domination in households and made marriage a passport for women to gain access tofood; or forced the middle and lower class women to work. ${ }^{28}$

\footnotetext{
${ }^{21}$ Moghissi, Feminisme dan Fundamentalisme Islam..., p. 7

${ }^{22}$ Moghissi, Feminisme dan Fundamentalisme Islam..., p. 70

${ }^{23}$ Moghissi, Feminisme dan Fundamentalisme Islam..., p. 40

${ }^{24}$ Moghissi, Feminisme dan Fundamentalisme Islam..., p. 88-90

${ }^{25}$ Moghissi, Feminisme dan Fundamentalisme Islam..., p. 97-98

${ }^{26}$ Moghissi, Feminisme dan Fundamentalisme Islam..., p.99-100

${ }^{27}$ Moghissi, Feminisme dan Fundamentalisme Islam..., p. 103

${ }^{28}$ Moghissi, Feminisme dan Fundamentalisme Islam..., p. 106-107
} 
In chaptersix Moghissi explores Islamisationist policies of the fundamentalist states towards the legal rights of women in family life, law, paid work disputes, and opposition to the project of Islamisation. Moghissi uses the fight by Iranian womenfor democracy as a case study. In her opinion, the fundamentalismthat replaced the Shah Monarch in Iran is a real example of how the impact of state policies concerning women such as veiling, retribution, divorce and lower payments for women workers aggravated the female condition. In the meantime, Moghissi sees Iranian women as having resisted and adjusted within the regime; they have taken part in international conferences, economy, gender issues and participated in the Olympics, alluntil the regime restricted such activities and women were forced back to their 'natural' condition. ${ }^{29}$

As a final focal point, Moghissi explains Islamic feminism and its concerns and difficulties in defining feminist Islam. This difficulty is caused by women who challenge traditional Islamic laws and struggle for justice, as they do not call themselves feminists and more importantly they avoid appropriating Western feminist agendas. They were called Muslim feminists because of the Islamic character they possess . In addition, Moghissi states that people do not really know whether the use of Islamic symbols and terms are really based on their beliefs or are used as a political strategy to protect themselves. ${ }^{30}$

In conclusion, Moghissi is pessimistic about the improvement of the bargaining position of women in the Middle East. Although she thought that alterationswere possible viastrong networks with secular feminist groups, she sees the differences between secular and Islamic feminist agendas. These differences may form a barrier that is detrimental to future change for the position of women in Islamic societies. ${ }^{31}$

\section{Margot Badran}

Margot Badran conducted field work in Cairo regarding the birth and spread of the feminist movement in Egypt. She started her research by exploring the biographies of three feminist leaders from upper and middle class families, Huda Sha'rawi (1876-1946), Nabawiyah Musa (1886-1951), and Saiza Nabarawi. The remainder of the text discusses their experiences in improving their own conditions, their contributions towards the development of Egyptian women and women in surrounding states, their roles in Egypt gaining independence and advocating for policies that would improve the conditions and social welfare of women. Badran handled the historical resources she found in Egypt to reconstruct the historical foundations of the feminist movement in the area. ${ }^{32}$

Badran started with the bibliography of Huda Sha'rawi, an upper class woman who was born into a wealthy family and married to a leader of the Wafd Party. According to Badran, due to the patriarchal dominance in Egyptian families, Sha'rawi experienced a lack of appreciation in her young age. However, her brother was

\footnotetext{
${ }^{29}$ Moghissi, Feminisme dan Fundamentalisme Islam..., p. 134-136

${ }^{30}$ Moghissi, Feminisme dan Fundamentalisme Islam..., p. 102-3, 169-170

${ }^{31}$ Moghissi, Feminisme dan Fundamentalisme Islam..., p. 186

${ }^{32}$ Margot Badran, Feminism in Islam. (Oxford: One World, 2009), p.31
} 
supportive of her efforts to improve herself as a young woman. ${ }^{33}$ In later life, Sha'rawi worked in the media and was active in helping lower class women, educating young women, and promoted the freedom of Egypt. She was the founder of the Egyptian Feminist Union (EFU), the first organised philantrophic feminist movement that provided food, health necessities, and economic improvement. In 1923, Sha'rawi became the head of this institution. ${ }^{34}$ The EFU's activities inspired the Egyptian government to establish the Ministry of Social Affairs. In 1923 Sha'rawi unveiled, and proclaimed that the veil had become the biggest hindrance for Egyptian womento participatein public affairs.$^{35}$

Following Sha'rawi, Badran investigatedNabawiyahMusa, ateacher, a school principal, and an advocate for young women's education. She came from a middle classbackgroundand her father was an army captain.Similar to Sha'rawi, Musa had a brother, 'the protector', that his presence utilized by Badran to gain a wide range of educational resources in herinformative years. She also belonged to the EFU organisation but focused her feminist activities on social services and professional issues. Musa criticized educational policies and the behavior of state employees. She established and rantwo private schools for girls, founded her own journal, produced books, and was the first woman to experience gender pay equality. ${ }^{36}$

Saiza Nabarawi, a European woman married to an Egyptian man,was the colleague and assistant of Sha'rawi. Nabarawi became the vice president of EFU, and worked as journalist, editor, and promote resistance toward males domination over women.She criticizes the government of sexism,besides proclaimed as anti colonialism, anti government protest, and anti imperial feminism. ${ }^{37}$

Badran found that the feminists greatly contributed to the areas of education, the professions, politics, international networks, and reformation in Islamic jurisprudence, especially that concerned with family issues.In the fieldof education, the EFU demanded better educational opportunities for young women and encouraged them to continue to a higher studies. ${ }^{38}$ Badran found that some male feminists, such as Murqus Fahmi,improved women's rights. In Fahmi's opinion, the backwardness of Egyptian culture correlated with gender inequalities. ${ }^{39}$ According to Badran, the feminist emphasizes that priority should be placed in prioritising the education of young females at a national level, as Egyptian culture already perceives mothers as the primary educators for the nation. Musa argued that both sexes should study the same academic curriculum. ${ }^{40}$ The feminist movement also fights to have access to other professions, and minimise the monopoly that men heldon thelabour market, law and journalism fields.

\footnotetext{
${ }^{33}$ Badran, Feminism in Islam..., p.37

${ }^{34}$ Badran, Feminism in Islam..., p. 96, 26, 111-112

${ }^{35}$ Badran, Feminism in Islam..., p. 23, 93

${ }^{36}$ Badran, Feminism in Islam..., p. 26, 39, 45

${ }^{37}$ Badran, Feminism in Islam..., p. 161, 211-212, 226, 232, 248-9

${ }^{38}$ Badran, Feminism in Islam..., p. 8-9,142

${ }^{39}$ Badran, Feminism in Islam..., p. 17

${ }^{40}$ Badran, Feminism in Islam..., p. 63
} 
According to Badran, the feminist movement had opposed the wide range of religious jurisprudence. For instance they viewed the veil as symbol of the harem culture, designed to keep women controlled, inferior, and imprisoned for the benefit of men.Feminists also strived to restrict polygamy due to the potential psychological damage it could cause to women involved in those relationships. They also urged for review of divorce regulations; being that men can file for divorce only under serious circumstancesand in the presence of a qadi (judge). Similarly, in relation to the issue of child custody, they advocated shrinking 'iddah (waiting periods for a woman after divorce or death of her husband before she could marry another man). ${ }^{41}$

Badran claimed that the feminist movement in Egypt contributed a great deal towards the development of Egypt's political sphere. This wasmost evidentduring the struggle for independencethrough the management of demonstrations, taking part in strikes, setting up apolitical organisation (in coordination with the Wafd National Organisation), and campaigning for nationalist interests abroad. ${ }^{42}$ The EFU produced a journal in France L' Egyptienne to amend the national image of Egypt abroad, and built an international network with a leading western feminist organisation, the International Alliance of Women for Suffrage and Equal Citizenship (IAW), but the relationship weakened as the European feminists did not support political development in Egypt and Palestine in the face of colonisation. ${ }^{43}$

From the comparative examination of the biographies of Sha'rawi, Musa and Nabarawi, Badran shows us how the Egyptian gender system, implanted with patriarchal authoritarianism places pressures on women to improve their conditions in civilian rights, family structure, social life, professions, and religious policies. Their struggle contributed a great deal to the alteration of theEgyptian gender system, and produced breakthrough and changes to government policies regarding women's issues. The condition of Egyptian women, once deemed asharem imprisonment, has since elevated to an improved quality of life.

\section{Findings}

From some of the above discussions with several Muslim feminists like Wadud's conclusion. Wadud has contributed a great deal in explaining gender issues, and encountering male domination in interpreting verses about women. God, in fact rewards people not based on their gender status but based on their deeds and pities (taqwa). And regardless some weaknesses, she has done her best to promote the rights of women in the Islamic world.

Meanwhile, Barlas proposes the ideas about egalitarian in Islam and liberation in interpreting Islamic sources from patriarchate domination. However she does not genuinely explore her own ideas since some of the ideas she proposes are already

\footnotetext{
${ }^{41}$ Badran, Feminism in Islam..., p. 69, 128-9, 131-133

${ }^{42}$ Badran, Feminism in Islam..., p. 13, 76-77

${ }^{43}$ Badran, Feminism in Islam..., p. 13
} 
widespread in Islam. In addition, she does not use and criticize the primary classical tafsir, and she mostly refers her ideas to the previous scholar's findings. However, in the positive side, Barla's work is valuable, since she was able to put 'these ideas which are already available in Islamic studies' into a book. So that it become a real contribution for academic work.

According to Sabah Mahmud, what happened in Egypt in terms of the spirit of Islamic revivalism has some similarities with Indonesia. Many Indonesian women, together with men, join Islamic preachings where the preachers consists of males and females. The impact of secularization in Indonesia was also answered by building modern Islamic schools suchas Al-Azhar schools, and modern pesantren (Islamic boarding schools), in addition to the existing traditional pesantren. More radically, various institutions ranging from liberal to the most fundamental emerged in Indonesia. After the fall of the new order regime, the Indonesian government established freedom of press. As a result, society, including Islamic groups, have more freedom to speak, voice their opinions, and even set up political organizations. This gives Indonesian Muslim women and men more opportunity and freedom to express their Islamic and political views, which is difficult to do in Egypt. However, although Indonesians mosques have Islamic teachings, they only focus on prayers matters, not entering further into the field of gender or other serious social political issues.

Moghissi is pessimistic about the improvement of the bargaining position of women in the Middle East. Although she thought that alterationswere possible viastrong networks with secular feminist groups, she sees the differences between secular and Islamic feminist agendas. These differences may form a barrier that is detrimental to fut ure change for the position of women in Islamic societies.

From the comparative examination of the biographies of Sha'rawi, Musa and Nabarawi, Badran shows us how the Egyptian gender system, implanted with patriarchal authoritarianism places pressures on women to improve their conditions in civilian rights, family structure, social life, professions, and religious policies. Their struggle contributed a great deal to the alteration of theEgyptian gender system, and produced breakthrough and changes to government policies regarding women's issues. The condition of Egyptian women, once deemed asharem imprisonment, has since elevated to an improved quality of life 


\section{REFERENCES}

Badran, Magot, Feminism in Islam. Oxford: One World, 2009.

. "Islamic Feminism Revisited". Al-Ahram Weekly Online, 9-15 February 2006, issue No. 781,

Barlas,Asma, 2002, believing Women in Islam:Unreading Patrarchal Interpretations of the Qur'an, (Austin : University of Texas)

Mahmood, Saba, Politics of Piety: The Islamic Revival and the Feminist Subject, Cairo: Princeton Uniersity Press, 2004

Moghissi. Haideh, Feminisme dan Fundamentalisme Islam, Yogyakarta: Lkis, 2005.

Wadud, Amina, Quran and Women : Rereading The Sacred Tect From A Woman' Perspective, New York : Oxford University Press, 1999 